\title{
Kommentar
}

\section{Når innsikt hindrer utsyn}

Paraneoplastiske tilstander har vært omtalt flere ganger i Tidsskriftet de senere årene (1-4). Disse tilstandene kan være multisymptomatiske, ofte spesialitetsovergripende, og derfor vanskelig diagnostiserbare. Gran og medarbeideres interessante kasuistikk illustrerer dette.

Kasuistikken viser et pasientforløp der svært mange sykehusspesialiteter var involvert. Det var ikke mangel på tilgang til spesialister og avansert diagnostikk som hindret at diagnosen ble stilt på et tidligere tidspunkt, men mangel på at noen så alle symptomene og prøveresultatene $\mathrm{i}$ en bredere sammenheng, for eksempel når leverenzymverdiene fortsatte å stige til tross for at acitretin ble seponert. Slik sett illustrerer kasuistikken det fragmenterte ved den høyspesialiserte helsetjenesten. Det kan ha stor betydning for diagnostikken hvilken spesialitet man kommer til med sine symptomer. Enkelte kommersielle aktører annonserer med «direkte til spesialist», som om det skulle være et ubetinget gode. I enkelte tilfeller kan faktisk den spesialiserte innsikten blokkere for det diagnostiske utsynet, slik at mønsteret i den utypiske kliniske presentasjonen ikke oppdages.

Det er derfor moderne klinisk medisin også i stor grad handler om samarbeid. Det er lett å undervurdere betydningen av møteplasser mellom de ulike spesialitetene i den kliniske hverdag. Slike møteplasser er viktig for å muliggjøre kommunikasjon som kan utvide den diagnostiske horisont. Verdifulle innspill kan bli fanget opp og diskutert, slik at man kan unngå tidsødende forfølgelse av diagnostiske blindspor. Som forfatterne fremholder, kunne en bedre kommunikasjon mellom radiolog og kliniker i dette tilfellet ha avslørt at hemangiomer i lever ikke kunne forklare de kliniske og laboratoriemessige funnene.

Flere sykehus er under press for å avvikle røntgenmøter, legemøter og andre tverrfaglige møter som ikke er «produktive» i direkte økonomisk forstand. Som klinikere må vi tydelig presisere betydningen av slike møter. En viktig grunn til å ha en høyspesialisert helsetjeneste er nettopp også å kunne gjenkjenne og å diagnostisere det uvanlige. Som kasuistikken illustrerer, krever dette både dybdeinnsikt $i$ eget fag så vel som mulighet til å trekke veksler på kompetanse fra andre fagfelt enn ens eget.

\section{Are Brean}

are.brean@siv.no

Tidsskriftet

Oppgitte interessekonflikter: Ingen

Litteratur

1. Storstein A, Vedeler CA. Paraneoplastiske nevrologiske syndromer. Tidsskr Nor Legeforen 2009; 129: $524-8$.

2. Storstein A, Bru A, Vedeler CA. Limbisk encefalitt en diagnostisk utfordring. Tidsskr Nor Lægeforen 2007; 127: 3077-80.

3. Ræder H, Kildahl-Andersen O. En mann med dyp venetrombose, transitorisk iskemiske anfall og stigende senkningsreaksjon. Tidsskr Nor Lægeforen 2002; 122: 507-10

4. Haga $H$, Johnsen $V$, Østensen $M$ et al. Myalgi og høy senkning hos voksne. Tidsskr Nor Lægeforen 2000; 120: $3405-8$.

Manuskriptet ble mottatt 11.9. 2009 og godkjent 24.9. 2009. Medisinsk redaktør Siri Lunde. 